higher incidence of ANA than the other beta-blockers in both male and female groups, but there were too few patients for this to be significant, and more patients are being sought. Most of the ANA-positive patients were also on treatment with methyldopa.

If the non-practolol beta-blockers are shown eventually to precipitate practolol-like reactions-even if all are associated with ANA - the assay will have little value as a screen for at-risk patients because of the many hypertensive patients who are ANA-positive. Most of these patients are taking methyldopa, which confirms the original observation of Breckenridge $e t$ al $^{2}$ that this drug induces ANA in over $10 \%$ of patients. Apart from the occasional case of methyldopa-induced lupus, however, there seems to be no clinical risk with this drug in patients who develop ANA.

The effects of beta-blockers and other hypotensive agents on other autoantibodies will be the subject of a later report.
This study was supported by a grant from the National Heart Foundation and by donations from the following drug companies: Ciba-Geigy New Zealand Ltd; ICI New Zealand Ltd; May and Baker New Zealand Ltd; Merck, Sharp, and Dohme (New Zealand) Ltd; Pharmaco (New Zealand) Ltd; and Sandoz Pharma Ltd.

Requests for reprints should be addressed to Professor J D Wilson.

\section{References}

1 Wright, P, British Medical fournal, 1975, 1, 595.

2 British Medical fournal, 1977, 1, 529.

${ }^{3}$ Marshal, A J, et al, Quarterly fournal of Medicine, 1977, 46, 135.

4 Amos, H E, Brigden, W D, and McKerrow, R A, British Medical fournal, $1975,1,598$.

5 Bullock, J Y, Gilmore, L L, and Wilson, J D, fournal of Urology. In press.

6 Whittingham, S, et al, Australasian Annals of Medicine, 1969, 18, 130.

${ }^{7}$ Breckenridge, A, et al, Lancet, 1967, 2, 1265.

(Accepted 14 October 1977)

\title{
Immune status of children of immigrants to poliomyelitis
}

\author{
ELEANOR J BELL， ROSALINDA MCDAID， R D DEWAR， K M GOEL， D REID， N R GRIST
}

British Medical fournal, 1978, 1, 16-18

\section{Summary and conclusions}

Four ethnic groups of children from the Glasgow area155 Asians, 85 Africans, 85 Chinese, and 93 Scots-were examined for neutralising antibodies to poliovirus types 1,2 , and 3. Only seven of the 418 children had no detectable antibody, and of these, four were aged less than 7 months; none had received polio vaccine. The best-protected children were the Chinese $(93 \%$ with antibody to all three poliovirus types), followed by the African (81\%), Scottish (78\%), and Asian children (77\%).

We conclude that children of immigrants are no more vulnerable to poliovirus infection than their Scottish counterparts.

\section{Introduction}

Since the last outbreak of poliomyelitis in Scotland in 1962, at least eight poliovirus antibody surveys of different sections of the Scottish population have been carried out. ${ }^{1-4}$ Of these, four have disclosed potentially serious gaps in immunity. Because of the

Regional Virus Laboratory, Ruchill Hospital, Glasgow G20 9NB

ELEANOR J BELL, BSC, PHD, top grade scientist

ROSALINDA MCDAID, technical assistant

Communicable Diseases (Scotland) Unit, Ruchill Hospital, Glasgow G20 9NB

R D DEWAR, administrative officer

D REID, $M D$, DPH, director

Royal Hospital for Sick Children, Glasgow G3 8SJ

K M GOEL, MD, MRCP, consultant paediatrician

Department of Infectious Diseases, Ruchill Hospital, Glasgow G20 9NB

N R GRIST, FRCPED, FRCPATH, professor of infectious diseases increasing number of immigrants in the United Kingdom we decided to extend our polio antibody surveillance to include these ethnic groups, which in Scotland are centred mainly in the Glasgow area. A study of the prevalence of various pathogenic organisms (parasites, bacteria, and hepatitis B) among the children of immigrants in Glasgow had already been conducted, ${ }^{5}$ so we took the opportunity to investigate the polio-immune status of these children, from whom serum specimens and detailed sociological information had already been obtained. Four ethnic groups were investigated-namely, Asians (from the Indian subcontinent), Africans (from various parts of Africa), Chinese (from Hong Kong), and Scots (included as a control group).

\section{Subjects and methods}

Of the sera taken from 500 children in the original study, ${ }^{5}$ only samples collected during 1974-5 from 418 were available for virological examination; these comprised samples from 155 Asian, 85 African, 85 Chinese, and 93 Scottish children aged 4 months to 16 years. Details of sex, age distribution, social class, and country of birth are given in table I. Thirty-one per cent of the children of immigrants were born abroad, the proportion being highest among the Chinese $(51 \%)$.

The modified micrometabolic inhibition test ${ }^{6}$ was used to assess the specificity of neutralising antibodies to the three types of poliovirus. Titrations were started at a final serum dilution of $1 / 8$. All tests were carried out in parallel with British Standard Poliovirus Antisera types 1,2 , and 3 . Antibody titres below 8 were regarded as negative.

\section{Results}

Seven of the 418 children-namely, three Asians, two Africans, one Chinese and one Scot-had no detectable antibody to any poliovirus type (table II). None had received polio vaccine. Four were aged 4-7 months and were therefore too young for the polio vaccination programme, two were aged 1 year, and the Scot was 6 years old. After the completion of the study five of these seven children received a full course of polio vaccination, but the other two could not be traced. 
TABLE I-Details of children tested

\begin{tabular}{|c|c|c|c|c|c|c|c|c|c|c|c|c|c|c|c|c|c|}
\hline \multirow{2}{*}{\multicolumn{3}{|c|}{$\begin{array}{l}\text { Ethnic } \\
\text { group }\end{array}$}} & \multirow{2}{*}{$\underset{\text { tested }}{\text { No }}$} & \multicolumn{2}{|c|}{ Sex } & \multicolumn{5}{|c|}{ Age (years) } & \multicolumn{5}{|c|}{ Social class* } & \multicolumn{2}{|c|}{ Country of birth } \\
\hline & & & & $M$ & F & $<1$ & $1-2$ & $3-4$ & $5-9$ & $10-16$ & I & II & III & IV & V & UK & Other \\
\hline \multirow[t]{2}{*}{$\begin{array}{l}\text { Asian } \\
\text { African } \\
\text { Chinese } \\
\text { Scottish }\end{array}$} & $\begin{array}{l}\cdots \\
\cdots \\
\cdots\end{array}$ & & $\begin{array}{r}155 \\
85 \\
85 \\
93\end{array}$ & $\begin{array}{l}90 \\
42 \\
43 \\
38\end{array}$ & $\begin{array}{l}65 \\
43 \\
42 \\
55\end{array}$ & $\begin{array}{l}6 \\
4 \\
4 \\
3\end{array}$ & $\begin{array}{r}19 \\
8 \\
6 \\
9\end{array}$ & $\begin{array}{r}23 \\
8 \\
11 \\
11\end{array}$ & $\begin{array}{l}63 \\
34 \\
34 \\
40\end{array}$ & $\begin{array}{l}44 \\
31 \\
30 \\
30\end{array}$ & 15 & $\begin{array}{r}2 \\
30 \\
31 \\
14\end{array}$ & $\begin{array}{r}101 \\
40 \\
54 \\
69\end{array}$ & $\begin{array}{r}45 \\
6\end{array}$ & 7 & $\begin{array}{r}118 \\
65 \\
42 \\
93\end{array}$ & $\begin{array}{l}37 \\
20 \\
43\end{array}$ \\
\hline & To & & 418 & 213 & 205 & 17 & 42 & 53 & 171 & 135 & 15 & 77 & 264 & 51 & 7 & 318 & 100 \\
\hline
\end{tabular}

*Not recorded in four Scottish children.

TABLE II-Details of seven children negative for all three poliovirus types

\begin{tabular}{|c|c|c|c|c|c|}
\hline Nationality & $\begin{array}{c}\text { Age } \\
\text { (years) }\end{array}$ & Sex & $\begin{array}{l}\text { Country } \\
\text { of birth }\end{array}$ & $\begin{array}{l}\text { Social } \\
\text { class }\end{array}$ & $\begin{array}{l}\text { Oral polio } \\
\text { vaccine } \\
\text { status }\end{array}$ \\
\hline $\begin{array}{l}\text { Asian } \\
\text { African } \\
\text { Chinese } \\
\text { Scottish }\end{array}$ & $\begin{array}{r}1 \\
1 \\
<1 \\
<1 \\
<1 \\
<1 \\
<1 \\
6\end{array}$ & $\begin{array}{l}M \\
M \\
F \\
M \\
M \\
M \\
M\end{array}$ & $\begin{array}{l}\text { Scotland } \\
\text { Pakistan } \\
\text { Scotland } \\
\text { Scotland } \\
\text { Scotland } \\
\text { Hong Kong } \\
\text { Scotland }\end{array}$ & $\begin{array}{l}\text { III } \\
\text { II } \\
\text { V } \\
\text { II } \\
\text { II } \\
\text { II } \\
\text { III }\end{array}$ & $\begin{array}{l}\text { Nil } \\
\text { Nil } \\
\text { Nil } \\
\text { Nil } \\
\text { Nil } \\
\text { Nil } \\
\text { Nil }\end{array}$ \\
\hline
\end{tabular}

The antibody status of the four ethnic groups is given in the figure. The best-protected children were the Chinese $(93 \%$ with antibody to all three poliovirus types), followed by the African ( $81 \%$ ), Scottish $(78 \%$ ), and Asian children (77\%). The most vulnerable group among the Asians were children aged up to 2 years, three of the 25 tested being triply susceptible; in the African and Chinese children it was those aged under 1 year-of the eight tested, four were triply susceptible and two doubly susceptible. In the Scottish children the younger age groups showed susceptibility to two poliovirus types, mainly types 1 and 3 ; the one triply susceptible child was in the 5-9-year age group. Irrespective of ethnic group the antibody status of the 5-9-year-olds was poorer than that of the 10-16-year-olds (although in the Africans the difference was small). This pattern of immunity was repeated when antibodies to the individual polioviruses were examined (table III). In each ethnic group antibody to type 2 virus was present more often than antibody to type 1 or 3

The polio vaccination status of these children had not been noted in the original study, ${ }^{5}$ and we therefore tried to get this information retrospectively. We were successful for all but 14 of the 93 Scottish children-66 $(84 \%)$ of whom had received a full course of vaccination, and only $6(8 \%)$ had never been vaccinated-but for almost none of the children in the other ethnic groups. This highlights the difficulty of retrieving computerised data on a population that is not only immigrant but also migrant.

\section{Discussion}

Previous poliovirus antibody surveys in the West of Scotland ${ }^{1-4}$ have shown protection rates varying from $93 \%$ in a prison population 4 to $49 \%$ in a group of pre-school children. ${ }^{2}$ Until now no data have been available on children of immigrants in this area of Scotland; it was therefore encouraging to find that the immune status of these children was in general better than that of the Scottish children, with the Chinese being the least susceptible group. That about one in four of the Scot- tish and Asian children lacked antibody to one or more polioviruses is disturbing, particularly as the deficiency was mostly in antibodies to types 1 and 3, which are more often associated with paralytic poliomyelitis than type 2 . The results in the Asian and Scottish groups were similar, possibly because both groups were predominantly in social class III, whereas most of the Africans were in classes I and II and a third of the Chinese were in class II.

Of the 418 children investigated, only seven were susceptible to all three types of poliovirus, and of these, four were too young to have started the recommended course of polio vaccination. The recent recommendation of the Joint Committee on Vaccination and Immunisation that immunisation should begin at 3 months ${ }^{7}$ should help to overcome this problem.

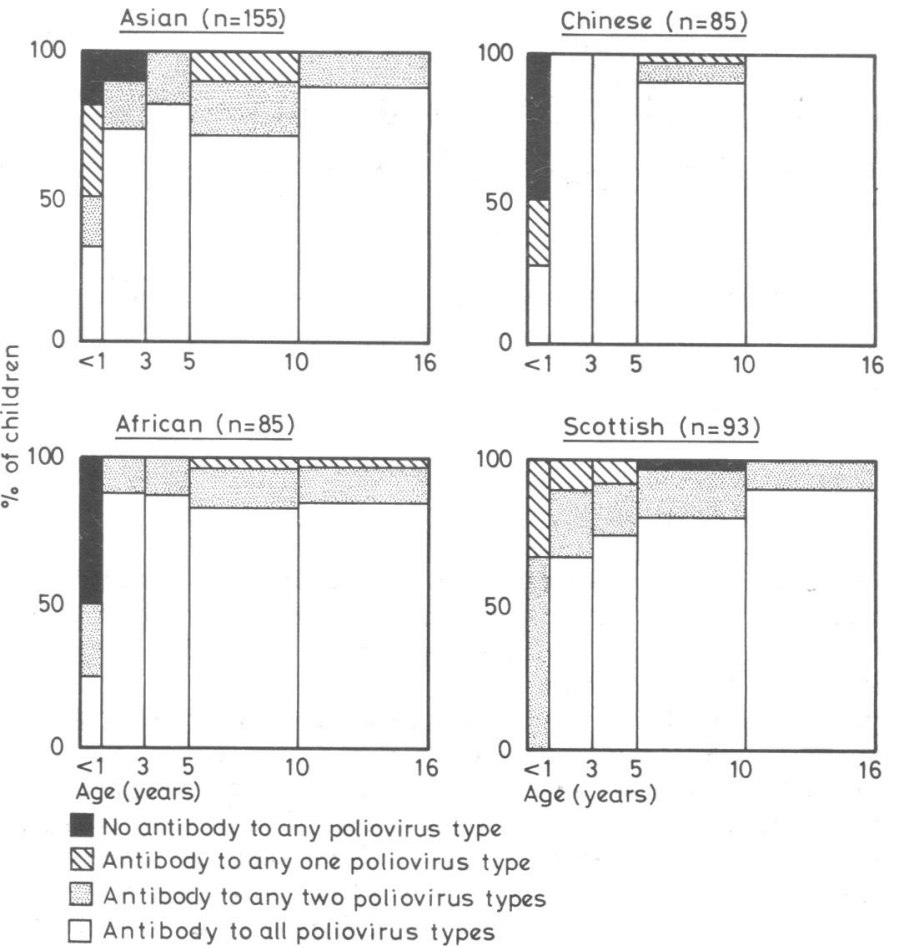

Poliovirus antibody status of the four ethnic groups.

TABLE III-Proportions of children with antibodies to poliovirus types 1,2 , and 3

\begin{tabular}{|c|c|c|c|c|c|c|c|c|c|c|c|c|c|c|c|c|}
\hline \multirow{2}{*}{$\underset{\text { (years) }}{\text { Age }}$} & \multicolumn{4}{|c|}{ Asians } & \multicolumn{4}{|c|}{ Africans } & \multicolumn{4}{|c|}{ Chinese } & \multicolumn{4}{|c|}{ Scots } \\
\hline & $\begin{array}{c}\text { No } \\
\text { tested }\end{array}$ & $\begin{array}{l}\% \text { with } \\
\text { type } 1 \\
\end{array}$ & $\begin{array}{l}\% \text { with } \\
\text { type } 2\end{array}$ & $\begin{array}{l}\% \text { with } \\
\text { type } 3\end{array}$ & $\begin{array}{c}\text { No } \\
\text { tested }\end{array}$ & $\begin{array}{l}\% \text { with } \\
\text { type } 1\end{array}$ & $\begin{array}{c}\% \text { with } \\
\text { type } 2\end{array}$ & $\begin{array}{l}\% \text { with } \\
\text { type } 3\end{array}$ & $\begin{array}{c}\text { No } \\
\text { tested }\end{array}$ & $\begin{array}{l}\% \text { with } \\
\text { type } 1\end{array}$ & $\begin{array}{l}\% \text { with } \\
\text { type } 2\end{array}$ & $\begin{array}{l}\% \text { with } \\
\text { type } 3\end{array}$ & $\underset{\text { tested }}{\text { No }}$ & $\begin{array}{l}\% \text { with } \\
\text { type } 1\end{array}$ & $\begin{array}{l}\% \text { with } \\
\text { type } 2\end{array}$ & $\begin{array}{l}\% \text { with } \\
\text { type } 3\end{array}$ \\
\hline $\begin{array}{c}<1 \\
1-2 \\
3-4 \\
5-9 \\
10-16 \\
\end{array}$ & $\begin{array}{r}6 \\
19 \\
23 \\
63 \\
44 \\
\end{array}$ & $\begin{array}{r}33 \\
84 \\
100 \\
86 \\
98 \\
\end{array}$ & $\begin{array}{r}83 \\
89 \\
100 \\
95 \\
100 \\
\end{array}$ & $\begin{array}{l}50 \\
79 \\
83 \\
81 \\
91 \\
\end{array}$ & $\begin{array}{r}4 \\
8 \\
8 \\
34 \\
31 \\
\end{array}$ & $\begin{array}{r}50 \\
100 \\
87 \\
91 \\
87 \\
\end{array}$ & $\begin{array}{r}50 \\
100 \\
100 \\
100 \\
100\end{array}$ & $\begin{array}{r}25 \\
87 \\
100 \\
88 \\
93\end{array}$ & $\begin{array}{r}4 \\
6 \\
11 \\
34 \\
30\end{array}$ & $\begin{array}{r}50 \\
100 \\
100 \\
88 \\
97\end{array}$ & $\begin{array}{r}25 \\
100 \\
100 \\
97 \\
100\end{array}$ & $\begin{array}{r}25 \\
100 \\
100 \\
97 \\
97\end{array}$ & $\begin{array}{r}3 \\
9 \\
11 \\
40 \\
30\end{array}$ & $\begin{array}{l}66 \\
89 \\
91 \\
87 \\
90\end{array}$ & $\begin{array}{r}100 \\
100 \\
100 \\
95 \\
100\end{array}$ & $\begin{array}{r}0 \\
67 \\
73 \\
92 \\
100\end{array}$ \\
\hline Total & 155 & 89 & 96 & 82 & 85 & 88 & 98 & 88 & 85 & 92 & 95 & 94 & 93 & 88 & 98 & 87 \\
\hline
\end{tabular}


So far as we are aware there are no reports on the poliovirus immunity of immigrants in the United Kingdom. Our results show that the children of immigrants in the Glasgow area do not constitute a health hazard with regard to poliomyelitis. This contrasts with reports from several other countries that children of immigrants predominate among the few residual cases of poliomyelitis, presumably because their parents may be less aware of the importance of immunisation than parents indigenous to the recipient, developed country. ${ }^{8-11}$

The present poliovirus activity in the United Kingdom12 cases so far during $1977^{12}$ - underlines the danger of complacency, which is becoming widespread owing to the dramatic reduction in the incidence of paralytic poliomyelitis since the introduction of polio vaccination programmes. This and the fact that children commonly accompany their parents on intercontinental journeys increase the chance of non-immune travellers mixing with people from countries where poliomyelitis is still endemic; conversely, emigrants from such areas are flocking to countries of high industrial development.

Antibody surveys are a more reliable method of assessing immunity than either statistics of vaccine uptake or waiting for sporadic cases or outbreaks of paralytic poliomyelitis to signal a dangerous decline of immunity due to complacent undervaccination or to technical flaws in the vaccination procedure. Our investigations again emphasise the continued need for polio vaccination in the first year of life and the importance of revaccination, irrespective of ethnic group, at school entry and leaving age, when children can be "administratively captured."
We thank Dr F T Perkins, of the MRC Laboratories, Hampstead, London, for the British Standard Poliovirus Antisera types 1, 2, and 3, and the National Fund for Research into Crippling Diseases for financial support.

Requests for reprints should be addressed to Dr E J Bell.

\section{References}

${ }^{1}$ Reid, D, et al, Lancet, 1969, 1, 564

2 Reid, D, et al, Lancet, 1973, 2, 899.

${ }^{3}$ Bell, E J, Communicable Diseases (Scotland) Report, 1974, 74/16, 3.

${ }^{4}$ Bell, E J, Reid, D, and Grist, N R, in Abstracts of XV Symposium of European Association against Poliomyelitis and Other Virus Diseases, Vienna, 1975, 6.

${ }^{5}$ Goel, K M, et al, British Medical fournal, 1977, 1, 676.

- Kyriazopoulou, V G, and Bell, E J, Bulletin of the World Health Organization, 1972, 47, 171.

${ }^{7}$ Department of Health and Social Security, Whooping Cough Vaccination. London, HMSO, 1977.

${ }^{8}$ Melnick, J L, et al, fournal of the American Medical Association, 1969, 209, 1181.

- Celers, J, Martin-Bouyer, G, and Lew, R, in Proceedings of XIII Symposium of European Association against Poliomyelitis and other Virus Diseases, Helsinki, 1971, 13.

${ }^{10}$ Neuman-Haefelin, D, Haas, R, and Petersen, E E, Deutsche medizinische Wochenschrift, 1973, 98, 970.

${ }^{11}$ Heyne, D, Poliomyelite en Belgique Année 1974. Brussels, Ministère de la Santé Publique et de la Famille, 1975.

12 Young, S E J, personal communication, 1977.

(Accepted 12 October 1977)

\title{
Osteomalacic dialysis osteodystrophy : a trial of phosphate-enriched dialysis fluid
}

\author{
T G FEEST, M K WARD, H A ELLIS, P ALJAMA, D N S KERR
}

British Medical fournal, 1978, 1, 18-20

\section{Summary and conclusions}

To assess whether phosphate depletion is an aetiological factor in osteomalacic dialysis osteodystrophy we undertook a prospective trial of phosphate-enriched dialysis fluid, in association with oral $1 \alpha$-hydroxycholecalciferol, for this condition. Thirty patients started the trial; of the 27 who completed more than 6 months' treatment, 14 had iliac crest bone biopsies at the beginning and end of the treatment period. Side effects included pruritus, stiffness, and increase in corneal and vascular calcification. Only one patient showed histological improvement of osteomalacia, and eight deteriorated; in seven the osteitis fibrosa worsened. Myopathy showed some improvement in four patients, but became worse in four.

This treatment does not seem to have a place in the routine management of non-hypophosphataemic patients on dialysis.

\footnotetext{
Department of Medicine, Royal Victoria Infirmary, Newcastle upon Tyne

T G FEEST, MB, MRCP, senior registrar in nephrology

$M$ K WARD, MB, MRCP, lecturer in medicine

H A ELLIS, MD, FRCPATH, reader in pathology

P ALJAMA, LMS, MD, research fellow

D N S KERR, MSC, FRCP, professor of medicine
}

\section{Introduction}

In Newcastle upon Tyne and several other centres an appreciable proportion of patients on regular haemodialysis develop an incapacitating type of bone disease characterised by bone pain and numerous fractures accompanied by proximal myopathy. ${ }^{12}$ Histological examination shows osteomalacia, with few active osteoblasts and little or no osteitis fibrosa. Serum concentrations of alkaline phosphatase and parathyroid hormone are often raised only slightly or not at all. This syndrome has failed to respond to treatment with calcium carbonate and phosphate binders, ${ }^{3}$ vitamin $\mathrm{D}_{2}$ or dihydrotachysterol, ${ }^{3} 1 \alpha$-hydroxycholecalciferol, ${ }^{4}$ or $1-25$-dihydroxycholecalciferol, ${ }^{6}$ or the withdrawal of hepatic-enzyme-inducing drugs. A similar syndrome is sometimes seen in hypophosphataemic osteomalacia. ${ }^{7-9}$ Some patients with hypophosphataemia and osteomalacia being treated with dialysis have responded to phosphate therapy, ${ }^{1011}$ and it has been suggested that phosphate depletion may contribute to renal osteodystrophy. ${ }^{12} \mathrm{We}$ carried out a prospective trial of phosphate-enriched dialysis fluid in 30 patients for 6-12 months to see whether we could treat or prevent osteomalacia by improving phosphate balance.

\section{Patients and methods}

Thirty patients were entered in the trial, 15 men and 15 women, aged between 18 and 60 (mean 41) years. All had been on regular haemodialysis for more than 6 months, using Meltec Multipoint $1 \mathrm{~m}^{2}$ dialysers and Lucas Mark II proportionating units, and dialysing 5-7 hours three times a week against a dialysate calcium of $1.6 \mathrm{mmol} / 1$. 